\title{
Rancang Bangun Aplikasi Sistem Informasi Manajemen Rantai Pasok Distribusi Daging Sapi Nasional
}

\author{
Lidra Trifidya, Sarwosri, dan Erma Suryani \\ Jurusan Teknik Informatika, Fakultas Teknologi Informasi, Institut Teknologi Sepuluh Nopember (ITS) \\ Jl. Arief Rahman Hakim, Surabaya 60111 Indonesia \\ e-mail: sarwosri@if.its.ac.id
}

\begin{abstract}
Abstrak-Manajemen distribusi merupakan salah satu aspek penting dalam memastikan kelancaran distribusi produk dari produsen ke konsumen dengan cara yang efisien. Berdasarkan pendekatan Supply Chain Management (SCM), lemahnya sistem distribusi merupakan salah satu penyebab terjadinya disparitas harga serta kelangkaan stok pada komoditas bahan pokok terutama daging sapi. Dengan langkanya stok di berbagai daerah dapat menyebabkan peningkatan harga sehingga terjadi perbedaan harga yang tinggi antar wilayah. Kelancaran distribusi akan menjamin ketersediaan stok sehingga akan mampu memperbaiki permasalahan yang ada. Melalui pendekatan Supply Chain Management, distribusi daging sapi dapat lebih transparan dan dapat terlihat ketersediaan stock di berbagai wilayah. Pada tugas akhir ini, dibangun sistem informasi distribusi daging sapi dengan pendekatan Supply Chain Management. Aplikasi ini dibuat dengan menggunakan metode aplikasi berorientasi obyek dengan PHP serta menggunakan struktur basis data relational MySQL. Dalam melakukan perancangan sistem, terlebih dahulu dilakukan analisis sistem dengan mewawancarai stakeholder yang berkaitan dengan distribusi daging sapi. Hasil pengujian sistem informasi ini menunjukkan bahwa kebutuhan pengguna telah terpenuhi dan mampu membantu proses distribusi daging sapi.
\end{abstract}

Kata Kunci-Distribusi, Komoditas Daging Sapi, Sistem Informasi, Supply Chain Management.

\section{PENDAHULUAN}

$\mathrm{P}$ ENINGKATAN jumlah penduduk yang semakin tinggi dari tahun ke tahun berbanding lurus dengan tingginya permintaan terhadap daging sapi sehingga menyebabkan ketidak-seimbangan antar jumlah permintaan dan jumlah produksi daging sapi tersebut. Dengan adanya ketidakseimbangan ini menyebabkan seringnya terjadi kelangkaan stok daging sapi di berbagai wilayah di Indonesia. Selain diakibatkan oleh tingginya peningkatan jumlah penduduk, kurangnya stock juga dapat diakibatkan oleh kelemahan manajemen distribusi. Sistem distribusi yang lemah dapat menyebabkan terjadinya kelangkaan stock serta terjadinya disparitas harga di berbagai wilayah.

Salah satu upaya penyelesaian dari permasalahan distribusi daging sapi ini yaitu dengan menggunakan metode Supply Chain Management (Manajemen Rantai Pasok). Kegiatan rantai pasok daging sapi perlu dilakukan untuk memenuhi permintaan konsumen yang tersebar dibeberapa wilayah yang berbeda-beda di Indonesia dan juga jumlah permintaan konsumen yang tidak pasti. Sehingga distribusi daging sapi dapat lebih efektif dan optimal.

Pada tugas akhir ini dirancang model distribusi dengan pendekatan Supply Chain Management. Adanya penggunaan teknologi internet dalam penerapan SCM berbasis web dapat mengintegrasikan antara supplier, distributor dan konsumen akhir secara real-time dan online sehingga memudahkan antar pihak dan dapat menghasilkan koordinasi yang baik. Dengan adanya sistem informasi ini alur informasi mengenai ketersediaan jumlah barang diberbagai wilayah akan lebih transparan. Seluruh proses transaksi yang terjadi akan dicatat dan di-update terus-menerus sehingga jumlah ketersediaan barang akan diketahui. Dengan adanya data yang ter-record dan terus di-update, maka akan memudahkan dalam mengembangkan analisis supply dan demand forecasting sehingga dapat memprediksi jumlah stock secara akurat. Dengan adanya sistem informasi ini diharapkan distribusi daging sapi di berbagai wilayah lebih transparan dan terlihat stok yang tersedia sehingga bisa menghindari terjadinya fluktuasi harga daging sapi.

\section{DASAR TEORI}

\section{A. Komoditas Daging Sapi}

Komoditas daging sapi merupakan salah satu komoditas prioritas dalam pembangunan nasional dalam upaya mewujudkan ketahanan pangan asal hewani. Komoditas daging sapi termasuk kedalam Rencana Strategis Kementerian Pertanian 2015-2019 dalam upaya mencapai target sukses pembangunan pertanian yaitu pencapaian swasembada padi, jagung dan kedelai serta peningkatan produksi gula dan daging [1]. Kebutuhan daging sapi di Indonesia saat ini dipenuhi dari tiga sumber, yaitu peternakan rakyat (ternak lokal), industri peternakan rakyat (hasil penggemukan sapi ex-import), dan import daging dari luar negeri. Setiap tahun, Indonesia membutuhkan tambahan pasokan daging impor yang berasal dari 450.000 ekor sapi. Indonesia saat ini masih mengalami kekurangan pasokan sapi karena pertambahan populasi tidak seimbang dengan kebutuhan nasional [2].

\section{B. Supply Chain Management}

Supply Chain Management (Manajemen Rantai Pasok) 
merupakan proses pengelolaan seluruh aktivitas perencanaan dan pengelolaan barang dan jasa dari pembelian material, perencanaan produksi, proses transformasi dari produk masih dalam proses hingga menjadi produk jadi, dan penyimpanan baik bahan baku maupun produk jadi hingga penyampaian produk jadi ke kustomer akhir melalui sistem distribusi [3].

Terdapat 3 aliran proses yang terjadi dalam supply chain yaitu:

1. Aliran Material, yaitu aliran produk yang mengalir dari upstream ke downstream atau dari pemasok hingga ke pelanggan, contohnya bahan baku yang dikirim ke pabrik

2. Aliran Keuangan yang mengalir dari hilir ke hulu berupa invoice, term pembayaran, dan lain sebagainya.

3. Aliran Informasi terbentuk dari aliran material dan finansial. Aliran ini mengalirkan informasi dari supplier ke produsen berupa jumlah bahan baku yang dimilliki, status pengiriman dari bahan baku yang dipesan produsen, dll.

Manajemen Rantai Pasok memiliki 2 proses, yang pertama proses inbound terdiri dari penerimaan, penyimpanan, dan distribusi bahan-bahan masukan untuk menghasilkan produk dan jasa, kedua adalah proses outbound merupakan aktivitasaktivitas yang melibatkan distribusi produk yang sudah jadi ke pelanggan. Menurut [6] Supply Chain merupakan sistem yang terintegrasi yang mana menyingkronkan serangkaian proses bisnis yang saling terkait, seperti [4]:

1. Memperoleh raw material

2. Mengubah bahan baku yang diperoleh sehingga menjadi produk jadi.

3. Menambahkan nilai produk jadi.

4. Mendistribusikan produk jadi ke retailer atau customer.

5. Memfasilitasi pertukaran informasi antara pelaku bisnis (supplier, manufacturer, distributor, retailer, dan customer).

SCM bertujuan untuk meningkatkan efektifitas dan efisiensi dari biaya, waktu, transaksi, dan mendapatkan kualitas yang lebih terjamin bagi barang atau jasa yang mengalir disepanjang rantai pasokan.

Tujuan manajamen rantai pasok sendiri selain untuk memenuhi permintaan konsumen juga untuk menguntungkan pihak-pihak supply chain yang terkait. Perencanaan rantai pasok juga dilakukan untuk mengintegrasikan aspek-aspek produksi-distribusi-konsumen yang selama ini masih terpisah. Seperti peternak ditingkat produksi terpisah dengan pelaku distribusi yang dilakukan oleh pihak lain. Hubungan antar pihak tidak terdapat kerja sama jangka panjang yang memberikan manfaat antar pihak. Hal ini membuat rantai pasok menjadi tidak efisien.

\section{E-Supply Chain Management}

Electronic Supply Chain Management merupakan suatu konsep manajemen yang memanfaatkan teknologi informasi untuk mengintegrasikan seluruh pelaku bisnis yang terlibat pada rantai pasok. Dengan adanya electronic supply chain management menjadikan hubungan antara supplier, distributor dan customer lebih mudah dalam berbagi informasi. Dalam melakukan perancangan e-Supply Chain Management ada beberapa modul-modul yang harus diperhatikan, yaitu [5]:

Beberapa hal yang harus diperhatikan dalam perancangan $e$ -
Supply Chain Management [6], yaitu:

1. Customer and Service Management

Customer relationship menyediakan cara bagaimana hubungan dengan customer dibangun. Customer service memungkinkan pelanggan untuk melakukan pemesanan secara online, menyediakan sumber-sumber untuk informasi customer seperti ketersediaan produk, tanggal pengiriman dan status pemesanan [4].

\section{Manufacturing and Supply Chain Planning}

Sebelum menggunakan SCM, proses manufactur produksi barang dilakukan dengan cara peramalan historical. Dengan SCM sekarang ini, memproduksi barang berdasarkan kebutuhan customer sehingga pengadaan barang menjadi lebih efektif dan efisien [4].

\section{Supplier Relationship Management}

SRM merupakan proses sebuah perusahaan berhubungan dengan supplier-nya.

\section{Logistics Resource Management}

Dengan adanya e-SCM memudahkan perpindahan barang dan jasa di antara manufactur, distributor dan supplier ke konsumen akhir.

\section{ANALISIS DAN PERANCANGAN SISTEM}

\section{A. Deskripsi Umum Sistem}

Sistem informasi manajemen rantai pasok ini dibuat dengan tujuan untuk memudahkan pihak-pihak yang terkait dengan distribusi daging sapi untuk melakukan transaksi pemesanan berdasarkan jumlah stok barang tersedia serta jumlah permintaan barang. Sistem informasi ini bisa digunakan oleh orang-orang yang sudah terregistrasi pada sistem. Sistem informasi ini bisa memberikan informasi jumlah pasokan yang tersedia sehingga memudahkan customer untuk melakukan pemesanan. Sistem ini memiliki empat jenis pengguna yang memiliki tugas yang berbeda-beda, yaitu Administrator, Supplier, Distributor serta Klien.

Administrator berperan sebagai pengelola data user (klien, distributor, dan supplier). Pada sistem ini admin yang akan mengelola dan memantau keseluruhan proses transaksi yang terjadi. Supplier bisa menerima pemesanan barang dan juga menampilkan jumlah stok daging sapi yang tersedia. Peran distributor yaitu bisa melakukan pemesanan barang ke supplier dan juga menerima pemesanan dari customer. Distributor bisa menampilkan jumlah stok produk yang tersedia. Dan customer hanya bisa melakukan pemesanan produk daging sapi, melihat jumlah stok daging sapi yang tersedia dari setiap supplier maupun distributor.

\section{B. Usecase Diagram}

Berdasarkan hasil wawancara yang telah dilakakuan terhadap beberapa stakeholder yang terkait distribusi daging sapi, sistem informasi distribusi daging sapi memiliki beberapa fungsi utama, antara lain :

1. Dapat melakukan proses pemesanan produk

2. Dapat menerima notifikasi hasil pemesanan produk

3. Dapat menerima permintaan pasokan

4. Dapat melakukan proses inventori produk

5. Dapat menampilkan jumlah ketersediaan stok barang 
Usecase diagram yang telah dibuat untuk menggambarkan fungsionalitas dapat dilihat pada Gambar 1 . spesifikasi kebutuhan yang telah direncanakan pada kebutuhan

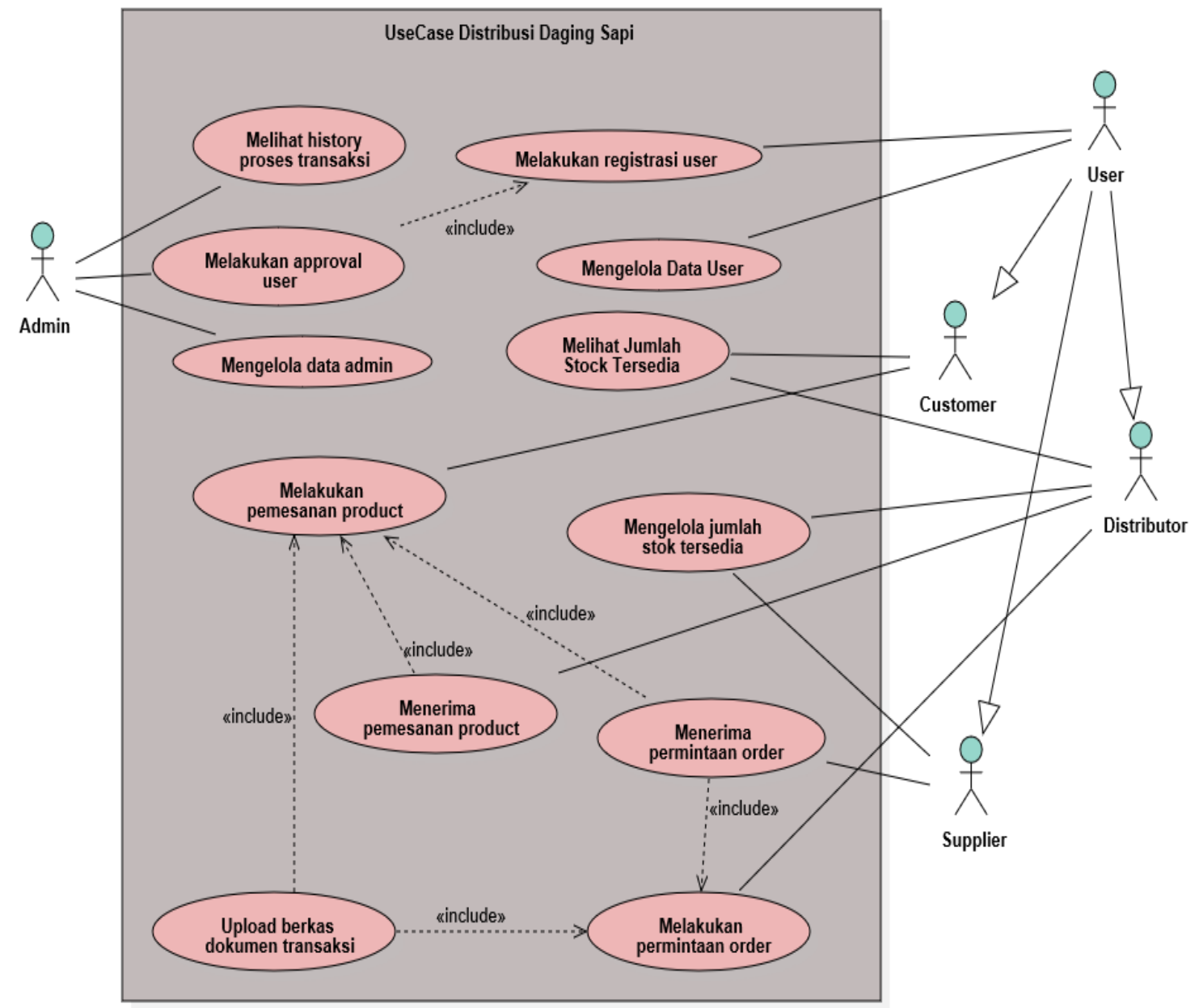

Gambar 1 Diagram kasus penggunaan

\section{Perancangan Arsitektur Sistem}

Arsitektur yang digunakan dalam pembuatan sistem informasi ini menggunakan arsitektur sistem framework CodeIgniter berbasis MVC pada setiap modul. Ilustrasi arsitektur CodeIgniter terdapat pada Gambar 2.

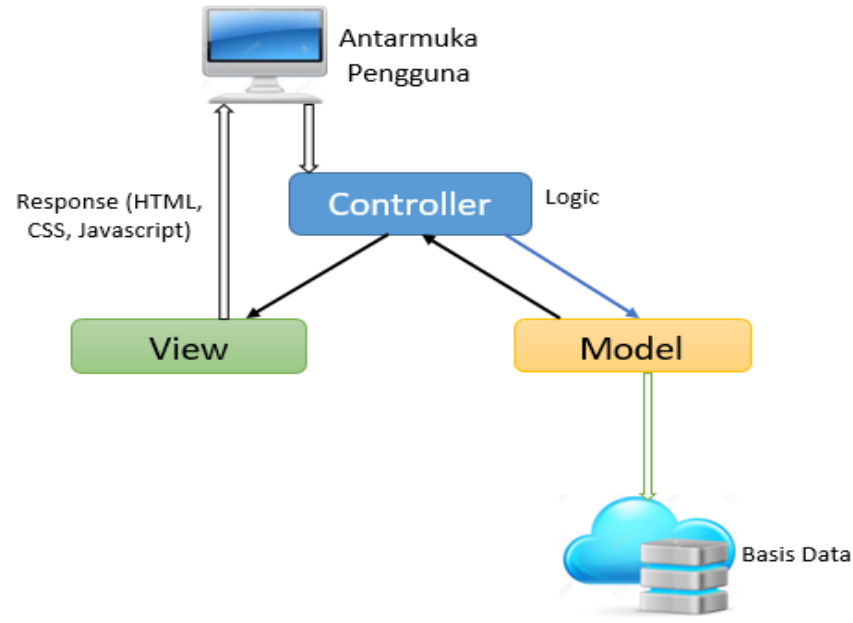

Gambar 2 Arsitektur model sistem informasi distribusi daging sapi

\section{IMPLEMENTASI}

Implementasi yang dilakukan menggunakan metode MVC (Model View Controller). Sehinnga sistem yang dibuat memiliki lapisan-lapisan yang direpresentasikan dalam kelas, yaitu view sebagai lapisan antarmuka pengguna, controller sebagai tempat untuk menerima request yang dikirim oleh aplikasi client atau browser, model sebagai tempat untuk melakukan pengelolaan terhadap basis data. Berikut ditampilkan source code implementasi pada bagian controller yang dapat dilihat pada Kode Sumber 1.

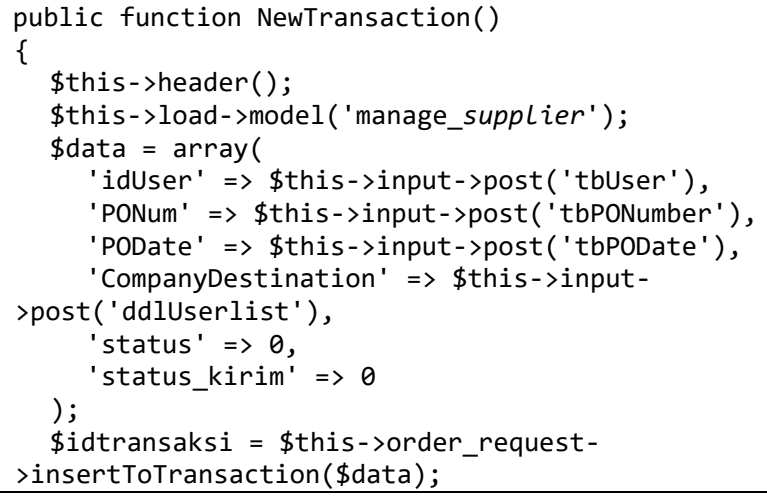




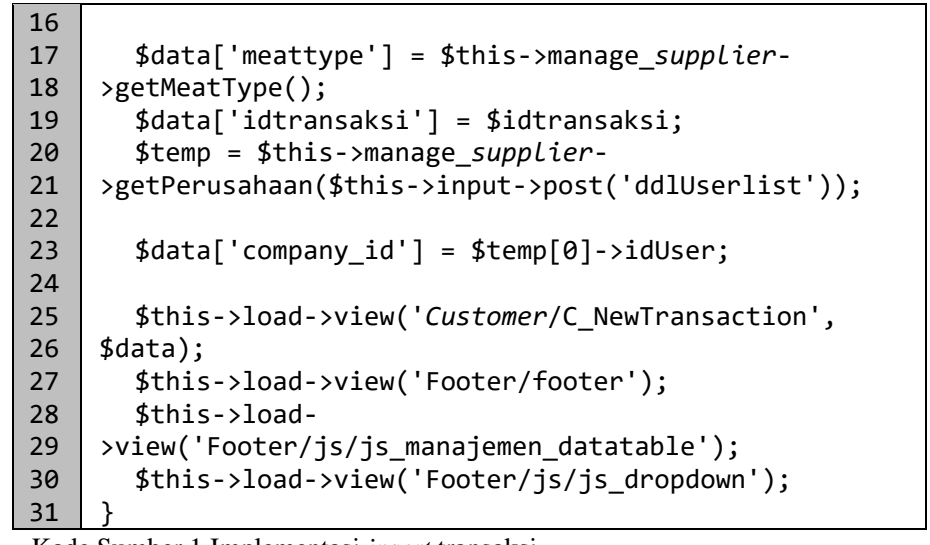

Kode Sumber 1 Implementasi insert transaksi

Gambar 3 menjelaskan halaman utama ketika pengguna masuk kedalam sistem distribusi daging sapi. Ketika pengguna membuka sistem informasi tersebut maka pengguna akan masuk ke halaman login. Gambar 4 menjelaskan halaman utama penerimaan transaksi yang telah dilakukan oleh konsumen.

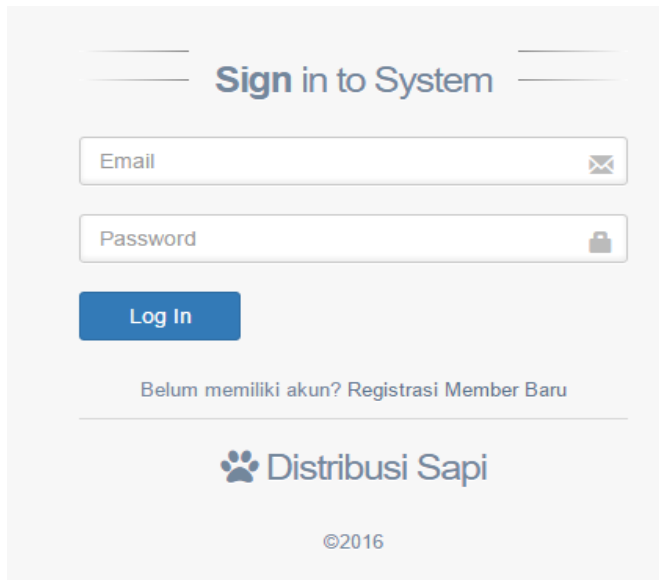

Gambar 3 Implementasi antarmuka halaman login

Permintaan Order

\begin{tabular}{|llccc|}
\hline Jenis Daging & Jumlah Pemesanan $(\mathrm{Kg})$ & Harga Barang $(\mathrm{Rp})$ & Total Harga (Rp) & Status Order \\
\hline Daging Punuk / Blade & 100 & 120000.00 & 12000000.00 & Belum Disetujui \\
\hline Daging Paha Depan / Chuck & 100 & 130000.00 & 13000000.00 & Belum Disetujui \\
\hline
\end{tabular}

\section{$\varangle$ Setuju $\quad x$ Tolak}

Gambar 4 Implementasi antarmuka halaman persetujuan transaksi

\section{PENGUJIAN DAN HASIL}

Pengujian yang dilakukan merupakan pengujian fungsionalitas yang menggunakan metode blackbox. Metode blackbox merupakan metode dimana pengujian ditekankan pada pola input dan output yang sesuai dengan skenario. Pengujian dilakukan dengan mengacu kasus penggunaan yang telah dijelaskan pada bab analisis dan perancangan sistem

Berdasarkan hasil pengujian yang telah dilakukan kepada responden yaitu pihak PT. Superindo Utama, diketahui bahwa semua kebutuhan fungsional yang ada telah berjalan sesuai skenario.

\section{KESIMPULAN/RINGKASAN}

Dari hasil uji coba yang telah dilakukan terhadap pembuatan sistem informasi akademik pada modul kurikulum, dapat diambil kesimpulan sebagai berikut:

1. Model bisnis dari sistem distribusi daging sapi merupakan sebuah sistem berbasis Manajemen Rantai Pasok yang telah disesuaikan dengan kebutuhan pengguna.

2. Pembagian aktor pada aplikasi dapat membantu aksesibilitas informasi ketersediaan stock komoditas bagi para stakeholder terlibat.

3. Aplikasi sistem informasi distribusi daging sapi sudah melalui analisis dan perancangan sistem dengan melihat kebutuhan fungsional dari proses bisnis distribusi daging sapi.

4. Aplikasi sistem informasi dapat melakukan transaksi berdasarkan jumlah stock yang tersedia. Pengguna dapat melakukan pemesanan produk berdasarkan jumlah stock yang tersedia serta pengguna dapat melihat status transaksi yang telah dilakukan.

5. Aplikasi sudah memenuhi semua kebutuhan fungsional dengan melakukan pengujian fungsionalitas terhadap perwakilan dari tiap pengguna sistem. 


\section{DAFTAR PUSTAKA}

[1] K. Pertanian, Rencana Strategis Kementerian Pertanian 2015-2019, Jakarta: Kementerian Pertanian, 2015.

[2] H. Soeprapto and Z. Abidin, "Cara Tepat Penggemukan Sapi Potong," Jakarta, PT Agromedia Pustaka, 2006.

[3] Setijadi, "Introduction to SCM," 2014. [Online]. Available: $\mathrm{http} / / /$ supplychainindonesia.com/new/wp-

content/files/1_Introduction_to_SCM_Man._Rantai_Pasok.pdf. [Accessed 812 2015].

[4] H. Min and G. Zhou, "Supply Chain Modeling: past, present and future," Journal of Computers and Industrial Engineering, 2002.

H. Soeprapto and Z. Abidin, "Cara Tepat Penggemukan Sapi Potong,"

[5] Jakarta, PT Agromedia Pustaka, 2006.

H. Min and G. Zhou, "Supply Chain Modeling: past, present and future,"

[6] Journal of Computers and Industrial Engineering, 2002. 